\title{
Anandamide injected into the lateral ventricle of the brain inhibits submandibular salivary secretion by attenuating parasympathetic neurotransmission
}

\author{
J. Fernandez-Solari1 ${ }^{1,2}$, J.P. Prestifilippo ${ }^{1}$, P. Vissio ${ }^{3}$, M. Ehrhart-Bornstein ${ }^{4}$, \\ S.R. Bornstein ${ }^{4}$, V. Rettori ${ }^{1}$ and J.C. Elverdin ${ }^{2}$
}

${ }^{1}$ Center for Pharmacological and Botanical Studies, National Council of Scientific and Technical Research, ${ }^{2}$ Department of Physiology, Dental School, ${ }^{3}$ Laboratory of Animal Embryology, Department of Experimental Biodiversity and Biology, School of Sciences, University of Buenos Aires, Buenos Aires, Argentina ${ }^{4}$ Department of Medicine Carl Gustav Carus, University Hospital, University of Dresden, Dresden, Germany

Correspondence to: J. Fernandez-Solari, Center for Pharmacological and Botanical Studies (CEFYBO-CONICET/UBA), Paraguay, 2155,1121 Buenos Aires, Argentina Fax: +54-11-4508-3680. E-mail: javierfsolari@yahoo.com.ar

Our objective was to determine the effect of arachidonylethanolamide (anandamide, AEA) injected intracerebroventricularly (icv) into the lateral ventricle of the rat brain on submandibular gland (SMG) salivary secretion. Parasympathetic decentralization (PSD) produced by cutting the chorda tympani nerve strongly inhibited methacholine (MC)-induced salivary secretion while sympathetic denervation (SD) produced by removing the superior cervical ganglia reduced it slightly. Also, AEA ( $50 \mathrm{ng} / 5 \mu \mathrm{L}$, icv) significantly decreased $M C$-induced salivary secretion in intact rats (MC $1 \mu \mathrm{g} / \mathrm{kg}$ : control (C), $5.3 \pm 0.6 \mathrm{vs} \mathrm{AEA}, 2.7 \pm 0.6 \mathrm{mg}$; MC $3 \mu \mathrm{g} / \mathrm{kg}$ : C, $17.6 \pm 1.0$ vs AEA, $8.7 \pm 0.9 \mathrm{mg} ; \mathrm{MC} 10 \mu \mathrm{g} / \mathrm{kg}$ : C, $37.4 \pm 1.2$ vs AEA, $22.9 \pm 2.6 \mathrm{mg})$. However, AEA did not alter the significantly reduced salivary secretion in rats with $P S D$, but decreased the slightly reduced salivary secretion in rats with SD (MC $1 \mu \mathrm{g} / \mathrm{kg}:$ C, $3.8 \pm 0.8$ vs AEA, $1.4 \pm 0.6 \mathrm{mg} ; \mathrm{MC} 3 \mu \mathrm{g} / \mathrm{kg}: \mathrm{C}, 14.7 \pm 2.4 \mathrm{vs} \mathrm{AEA}, 6.9 \pm 1.2 \mathrm{mg} ; \mathrm{P}<0.05 ; \mathrm{MC} 10 \mu \mathrm{g} / \mathrm{kg}: \mathrm{C}, 39.5$ \pm 1.0 vs AEA, $22.3 \pm 0.5 \mathrm{mg} ; \mathrm{P}<0.001$ ). We showed that the inhibitory effect of $A E A$ is mediated by cannabinoid type $1 \mathrm{CB} 1$ receptors and involves GABAergic neurotransmission, since it was blocked by previous injection of the CB1 receptor antagonist AM251 (500 ng/5 $\mu \mathrm{L}$, icv) or of the $\mathrm{GABA}_{\mathrm{A}}$ receptor antagonist, bicuculline $(25 \mathrm{ng} / 5 \mu \mathrm{L}$, icv). Our results suggest that parasympathetic neurotransmission from the central nervous system to the SMG can be inhibited by endocannabinoid and GABAergic systems.

Key words: Anandamide; Parasympathetic nervous system; Submandibular gland; Cannabinoid receptor type 1; Gamma-aminobutyric acid

Research supported by the University of Buenos Aires (UBACyT O 025), CONICET (PIP 6149), National Agency of Scientific and Technological Promotion (PICT 14264) and Fundación Alberto J. Roemmers.

Received August 14, 2008. Accepted March 24, 2009 


\section{Introduction}

The submandibular gland (SMG) is one of the major salivary glands, together with the sublingual and the parotid glands. The secretion of saliva is controlled by the autonomic nervous system. The parasympathetic nervous system exerts its function through the activation of muscarinic cholinergic receptors in the salivary glands via impulses through the chorda tympani nerve and the release of acetylcholine; salivation then depends on the contraction of myoepithelial cells embracing the acini and intercalated ducts (1). The sympathetic nervous system also induces salivary secretion by releasing norepinephrine that stimulates $\alpha$ - and $\beta$-adrenergic receptors (2). It was reported that pilocarpine, a muscarinic agonist, injected intracerebroventricularly (icv) induced salivary secretion by activating central autonomic efferent fibers (3). Other studies suggest that an important center for eliciting salivary secretion exists in the hypothalamus and involves cholinergic pathways. Numerous projections exist from the lateral hypothalamus to salivary nuclei located in the brain stem $(4,5)$. Lesions of the lateral or ventromedial hypothalamus impair salivary secretion induced by increased ambient temperature in rats $(5,6)$. Also, other experiments have demonstrated that warming or electrical stimulation of the preoptic area produces an increase in salivary secretion by the submandibular and sublingual glands (7), and lesions in the anteroventral third ventricle region reduce salivary secretion induced by pilocarpine injected intraperitoneally (ip) or icv (3).

The main psychoactive ingredient of Cannabis sativa, $\Delta^{9}$-tetrahydrocannabinol (THC), affects different physiological functions. Twenty years ago, two subtypes of G-protein-coupled cannabinoid $(\mathrm{CB})$ receptors were identified: the CB1 central receptor subtype, which is mainly expressed in the brain (8-10), and the CB2 peripheral receptor subtype, which appears to be particularly abundant in the immune system (11). A few years later, arachidonylethanolamide (anandamide, AEA) and arachidonoyl glycerol, the best-known endocannabinoids, were discovered and purified. Both endocannabinoids derive from arachidonic acid and bind with high affinity to $C B$ receptors (12). Selective antagonists have been developed for CB1 receptors, such as AM251 (13) and SR141716A $(14,15)$, and for CB2, such as AM630 (16) and SR144528 (17).

The salivary glands have secretory units, called acini, which are continuous with a ductal system. We reported previously that both $\mathrm{CB} 1$ and $\mathrm{CB} 2$ receptors are located in the SMG, mainly in the ductal system, and CB2 receptors have also been found in the acini (18). We also demonstrated that AEA injected into the SMG decreases the methacholine (MC)- and norepinephrine-stimulated salivary secretion. These inhibitory effects of AEA were blocked by injecting either the CB1 antagonist AM251 or AM630, a CB2 antagonist, into the SMG, confirming the presence and the biological effects of both $\mathrm{CB} 1$ and $\mathrm{CB} 2$ receptors in the SMG (18).

In contrast to classical neurotransmitters, endocannabinoids can function as retrograde synaptic messengers. They are released from postsynaptic neurons and travel backwards across synapses, activating CB1 receptors on presynaptic axons and suppressing neurotransmitter release (19). It has been demonstrated that THC decreased the electrically stimulated salivary flow in dogs by a mechanism involving a decrease in acetylcholine release, which results in reduction of blood flow to the SMG (20). There is evidence that AEA and THC abolished norepinephrine release in other systems by presynaptic inhibition (21). Also, it was reported that cholinergic neurons of the hippocampus co-express $C B 1$ and $G A B A_{B}$ receptors, suggesting a link between endocannabinoids and gamma aminobutyric acid (GABA), the main inhibitory neurotransmitter of the CNS (22). Therefore, it is possible that the endocannabinoid system modulates salivary secretion by acting not only directly on $\mathrm{CB}$ receptors in the salivary glands but also on $\mathrm{CB}$ receptors in the brain that could modulate the autonomic neurotransmission to the glands.

It is also known that endocannabinoids produce different effects by the activation of transient receptor potential vanilloid type 1 (TRPV1) channels reported to be located in the brain (23). Because TRPV1-expressing neurons were observed in the hypothalamus (23), this kind of interaction should also be considered to be a mechanism in the central control of salivary secretion.

Since it is known that the consumption of cannabinoids decreases salivary secretion and also alters synaptic neurotransmission, the aim of the present study was to determine the effect of the endocannabinoid AEA, injected into the lateral ventricle of the brain, on SMG salivary secretion. Additionally, since it was reported that some effects of AEA in the CNS were mediated by modulating GABAergic $(24,25)$ neurotransmission, we also studied the effects of AEA when GABA receptors were blocked.

\section{Material and Methods}

\section{Animals}

Adult male Wistar rats (250-300 g) from our own colony were kept in group cages in an animal room having a photoperiod of $12 \mathrm{~h}$ of light (7:00 to 19:00 h), room temperature of $22-25^{\circ} \mathrm{C}$ and free access to rat chow and tap water. 
The animals were divided into several experimental groups, 5-6 animals per group. The experimental procedures reported here were approved by the Animal Care Committee of the Center of Pharmacological and Botanical Studies, National Council for Research of Argentina and carried out according to NIH guidelines.

\section{Salivary secretion studies}

Salivary responses were determined in anesthetized rats $(100 \mathrm{mg} / \mathrm{kg}$ chloralose in $0.9 \% \mathrm{NaCl}, i v)$. The main duct of the right SMG was cannulated to obtain salivary secretion. Since resting (non-stimulated) flow of saliva is not observed in rats, the sialogogue MC was utilized to induce salivary secretion. Different doses of $\mathrm{MC}(1,3$, and $10 \mu \mathrm{g} / \mathrm{kg}$ in saline) were sequentially injected via the right femoral vein as previously described (26) and dose-response curves (DRC) of salivary secretion from the right SMGs were performed for each rat, before (control curves) and after the treatments described in the following paragraph. All control DRC were performed after the injection of the vehicle of each drug. The saliva secreted over a period of $3 \mathrm{~min}$ after the administration of each dose of $\mathrm{MC}$ was collected on aluminum foil and weighed. The period between two successive injections of MC was $5 \mathrm{~min}$. Results are reported as mg saliva per $3 \mathrm{~min}$.

To evaluate the participation of brain CB receptors in salivary secretion, a cannula was implanted into the lateral cerebral ventricle under tribromoethanol anesthesia $(3.5 \%$ in saline, $1 \mathrm{~mL} / 100 \mathrm{~g}$ animal body weight, ip) using a stereotaxic instrument 1 week prior to the day of the experiment. The coordinates relative to the interaural line (AP -0.6 mm, L -2 mm, DV -3.2 mm) were taken from the stereotaxic atlas of Pellegrino et al. (27). The adequate location of the cannula in the ventricle was confirmed by injecting a solution of methylene blue icv at the end of the experiment and confirming its position in histologic sections.

Fifteen minutes after control DRC, when the vehicle injected was saline containing $0.3 \%$ ethanol, AEA (50 ng/ $5 \mu \mathrm{L}$, icv) was injected. Fifteen minutes later, DRC were constructed to evaluate the effect of $A E A$ on salivary secretion. To study the effect of AEA when CB1 or CB2 receptors were blocked, AM251 (500 ng/5 $\mu \mathrm{L}$, icv) or AM630 (500 ng/5 $\mu \mathrm{L}, i c v)$, respectively, was injected 15 min prior to the injection of AEA. AM251 and AM630 were first dissolved in dimethylsulfoxide (DMSO) and further dilutions were made in saline, with the vehicle being saline with $10 \%$ DMSO. Additionally, the effect of AM251 and AM630 alone was studied. To study the effect of AEA when vanilloid receptors (TRPV1) were blocked, capsazepine (2 $\mu \mathrm{g} / 5 \mu \mathrm{L}$ ), a vanilloid receptor selective antagonist, was injected icv 15 min before the AEA. Capsazepine was also dissolved in DMSO (10\%). Additionally, the effect of capsazepine alone was studied. To determine the effect of $A E A$ on salivary secretion when $G A B A_{A}$ receptors were blocked, we used bicuculline $(25 \mathrm{ng} / 5 \mu \mathrm{L})$, which was dissolved in saline and injected icv $15 \mathrm{~min}$ before the injection of AEA. All studies were performed using 5-6 rats per group.

\section{Parasympathetic or sympathetic blockade studies}

To produce parasympathetic blockade of the SMG, the right chorda tympani nerve was cut, resulting in unilateral parasympathetic decentralization (PSD), while, to produce sympathetic blockade, the right superior cervical ganglia (SCG) was removed resulting in unilateral sympathetic denervation (SD), as previously described (28). To analyze the acute effect of PSD and/or SD per se on salivary secretion, the control DRC were constructed before the chorda tympani was cut and/or the SCG was removed. Thirty minutes after PSD and/or SD, the second DRC were constructed. To study the effect of AEA on PSD or SD rats, control DRC of salivary secretion from the right SMG were constructed for each animal 30 min after surgery. Fifteen minutes later, AEA was injected $i c v$, and after an additional $15 \mathrm{~min}$, the second DRC were constructed as described above.

\section{Statistical analysis}

Data are reported as means \pm SEM for 5-6 rats per group. The results obtained from salivary studies were analyzed by two-way ANOVA followed by the Bonferroni posttest. All analyses were conducted using the Prism software (GraphPad Software, Inc., USA). Differences with P values $<0.05$ were considered to be statistically significant.

\section{Immunohistochemistry}

The rats were anesthetized with tribromoethanol and perfused with $4 \%$ paraformaldehyde and $0.17 \%$ picric acid in PBS (0.05 M, pH 7.4) for 30 min. After perfusion, the hypothalami were dissected and post-fixed. Transverse slices $(10 \mu \mathrm{m})$ were cut with a cryostat and collected on gelatin-coated slides. Primary antibodies against CB1 receptors (1:1000) raised in rabbits were used (Affinity BioReagents, Inc., USA). Sections were developed using a secondary anti-rabbit antibody raised in goats (1:200) coupled to rhodamine (Vector Laboratories, UK). The slides were examined and the images were captured using a confocal laser microscope (Nikon C1, objective lenses Nikon 60X 1.40 Plan Apo, USA).

\section{Chemicals}

Bicuculline methobromide and arachidonylethanola- 
mide (anandamide, AEA) were purchased from Sigma (USA). Chloralose and methacholine (MC) were obtained from Fluka (Laborchemikalien, Germany). AM251 [N(piperidin-1-yl)-1-(2,4-dichlorophenyl)-5-(4-chlorophenyl)4-methyl-1H-pyrazole-3-carboxamide], AM630 [6-iodo-2methyl-1-[2-(4-morpholinyl)ethyl]-1H-indol-3-yl](4-methoxyphenyl)methanona] and capsazepine [N-[2-(4-chlorophenyl)ethyl]-1,3,4,5-tetrahydro-7,8-dihydroxy-2H-2benzazepine-2-carbothioamide] were obtained from Tocris $^{\mathrm{TM}}$ (Ellisville, USA).

\section{Results}

\section{Effect of PSD and/or SD on MC-stimulated salivary secretion}

Unilateral PSD decreased dramatically salivary secretion induced by $\mathrm{MC}$ as demonstrated by $\Delta$ saliva between post-treatment and control curves (Figure 1). However, unilateral SD decreased only slightly MC-induced salivary secretion. When PSD was followed by SD, the decrease of salivary secretion was not modified significantly as compared to PSD alone. Moreover, $\Delta$ saliva was significantly higher in PSD and PSD plus SD rats compared to SD rats, when secretion was induced by 3 and $10 \mu \mathrm{g} / \mathrm{kg}$ of MC.

Effect of AEA injected icv on MC-stimulated salivary secretion in intact rats or in rats with PSD or with SD

Intracerebroventricular injections of AEA (50 ng/5 $\mu \mathrm{L})$ reduced $M C$-induced salivary secretion in a statistically significant manner (Figure 2A). However, AEA had no effect on $\mathrm{MC}$-induced salivary secretion in rats that lacked

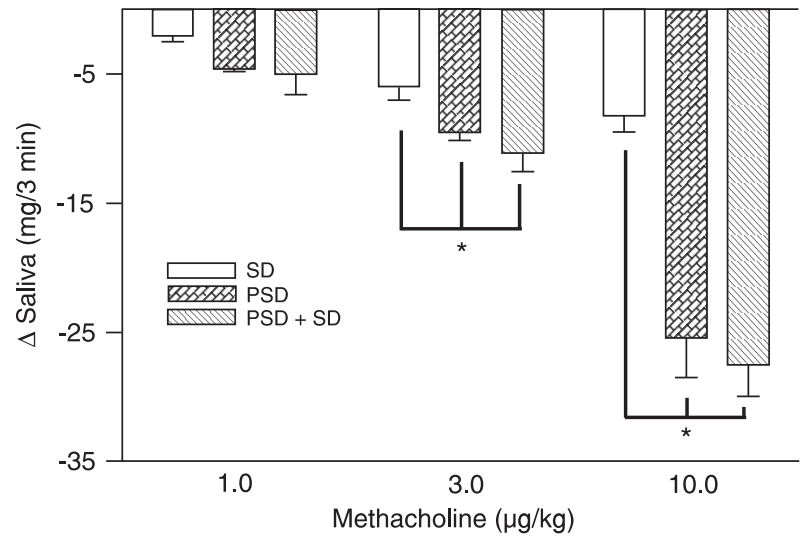

Figure 1. Effect of sympathetic denervation (SD), parasympathetic decentralization (PSD), and PSD plus SD on $\Delta$ saliva between control and post-treatment curves of methacholinestimulated salivary secretion. Data are reported as means of $\Delta$ saliva \pm SEM for 5 rats. ${ }^{*} \mathrm{P}<0.05$ vs SD (two-way ANOVA followed by the Bonferroni post-test).
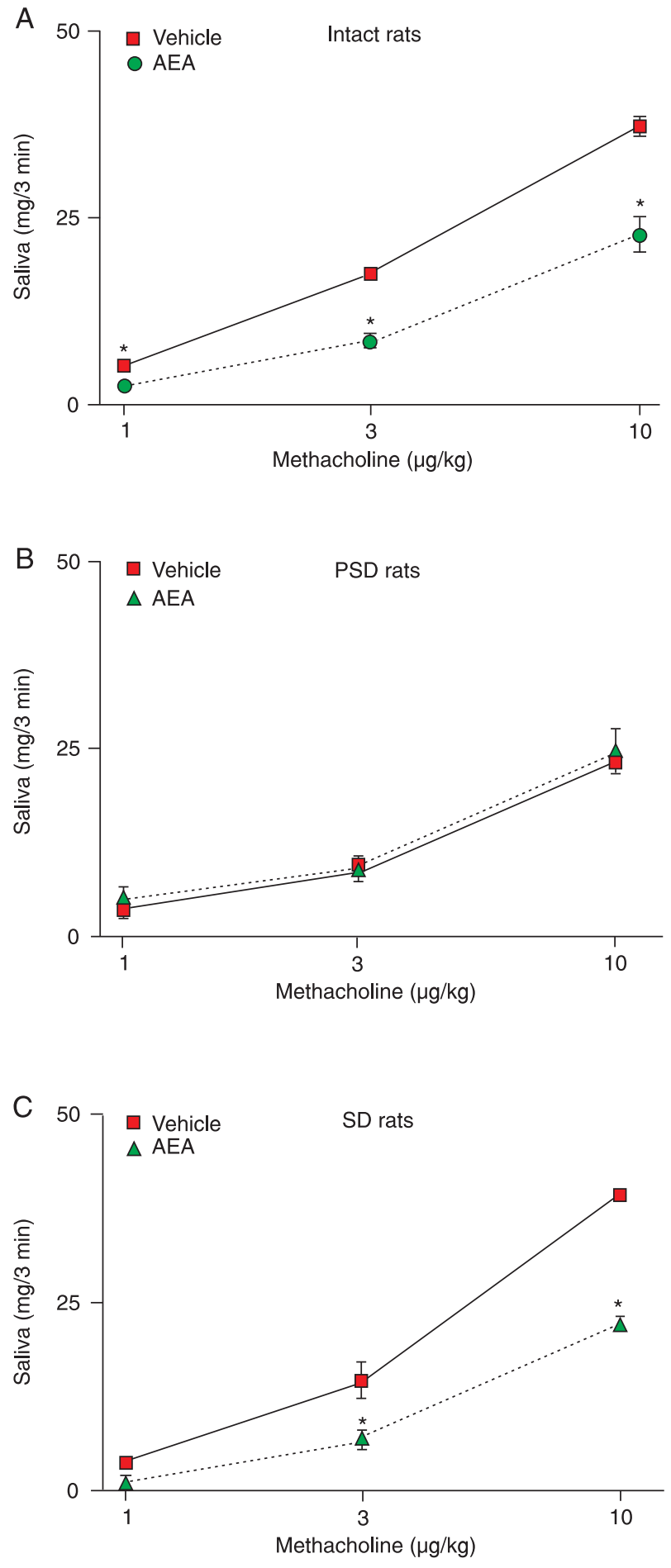

Figure 2. Effect of anandamide (AEA) $(50 \mathrm{ng} / 5 \mu \mathrm{L})$ injected icv on methacholine-stimulated salivary secretion in intact rats $(A)$ and in rats with parasympathetic decentralization (PSD) (B) or with sympathetic denervation (SD) (C). Data are reported as means \pm SEM for 5-6 rats. ${ }^{*} P<0.05$ vs vehicle injections (twoway ANOVA followed by the Bonferroni post-test). 
Table 1. Effect of anandamide, AM251 and/or bicuculline injected icv on methacholine (MC)-stimulated salivary secretion.

\begin{tabular}{|c|c|c|c|c|c|c|c|c|c|c|}
\hline \multirow{3}{*}{$\begin{array}{l}\text { MC } \\
(\mu \mathrm{g} / \mathrm{kg})\end{array}$} & \multicolumn{10}{|c|}{ Saliva (mg/3 min) } \\
\hline & \multicolumn{2}{|c|}{ AEA } & \multicolumn{2}{|c|}{ AM251 + AEA } & \multicolumn{2}{|c|}{ AM251 } & \multicolumn{2}{|c|}{ Bicuculline + AEA } & \multicolumn{2}{|c|}{ Bicuculline } \\
\hline & Pre & Post & Pre & Post & Pre & Post & Pre & Post & Pre & Post \\
\hline 1 & $5.3 \pm 0.6$ & $2.7 \pm 0.6^{*}$ & $6.3 \pm 1.3$ & $5.2 \pm 1.1$ & $4.2 \pm 1.0$ & $4.7 \pm 1.5$ & $5.0 \pm 0.6$ & $7.8 \pm 0.2$ & $5.2 \pm 1.6$ & $7.3 \pm 1.8$ \\
\hline 3 & $17.8 \pm 1.0$ & $8.7 \pm 0.8^{*}$ & $18.1 \pm 2.2$ & $12.6 \pm 2.0$ & $17.0 \pm 3.0$ & $18.0 \pm 3.8$ & $17.7 \pm 1.5$ & $15.3 \pm 0.9$ & $17.0 \pm 2.3$ & $22.3 \pm 0.7$ \\
\hline 10 & $37.4 \pm 1.2$ & $22.9 \pm 2.5^{*}$ & $37.0 \pm 3.3$ & $30.2 \pm 4.4$ & $38.0 \pm 1.2$ & $41.7 \pm 1.7$ & $38.9 \pm 1.0$ & $36.5 \pm 0.9$ & $36.3 \pm 2.0$ & $42.3 \pm 2.3$ \\
\hline
\end{tabular}

Data ( $\mathrm{mg}$ saliva/3 $\mathrm{min}$ ) are reported as means \pm SEM for $\mathrm{N}=5-6$ animals. The doses of anandamide (AEA), AM251 and bicuculline were 50,500 and $25 \mathrm{ng} / 5 \mu \mathrm{L}$, respectively. ${ }^{*} \mathrm{P}<0.05$ vs vehicle injection (two-way ANOVA followed by the Bonferroni post-test).

Table 2. Effect of anandamide, AM630 and/or capsazepine injected icv on methacholine (MC)-stimulated salivary secretion.

\begin{tabular}{|c|c|c|c|c|c|c|c|c|}
\hline \multirow[t]{3}{*}{$\mathrm{MC}(\mu \mathrm{g} / \mathrm{kg})$} & \multicolumn{8}{|c|}{ Saliva (mg/3 min) } \\
\hline & \multicolumn{2}{|c|}{ AM630 + AEA } & \multicolumn{2}{|c|}{ AM630 } & \multicolumn{2}{|c|}{ Capsazepine + AEA } & \multicolumn{2}{|c|}{ Capsazepine } \\
\hline & Pre & Post & Pre & Post & Pre & Post & Pre & Post \\
\hline 1 & $5.5 \pm 0.5$ & $3.2 \pm 0.6^{*}$ & $5.1 \pm 0.8$ & $5.2 \pm 1.1$ & $5.5 \pm 0.8$ & $3.1 \pm 0.7^{*}$ & $5.1 \pm 0.5$ & $5.0 \pm 0.7$ \\
\hline 3 & $21.5 \pm 1.5$ & $11.5 \pm 0.5^{*}$ & $21.9 \pm 1.3$ & $22.5 \pm 1.6$ & $22.3 \pm 1.1$ & $9.1 \pm 0.4^{*}$ & $19.2 \pm 1.5$ & $17.0 \pm 1.2$ \\
\hline 10 & $43.0 \pm 2.0$ & $23.0 \pm 2.0^{*}$ & $41.2 \pm 2.6$ & $39.9 \pm 3.0$ & $40.8 \pm 1.7$ & $20.4 \pm 1.0^{*}$ & $38.6 \pm 2.4$ & $36.5 \pm 1.5$ \\
\hline
\end{tabular}

Data ( $\mathrm{mg}$ saliva/3 $\mathrm{min}$ ) are reported as means \pm SEM for $\mathrm{N}=5-6$ animals. The doses of anandamide (AEA), AM630 and capsazepine were 50,500 and $2 \mu \mathrm{g} / 5 \mu \mathrm{L}$, respectively. ${ }^{*} \mathrm{P}<0.05$ vs vehicle injection (two-way ANOVA followed by the Bonferroni post-test).

parasympathetic inputs to the right SMG (PSD rats; Figure 2B). In animals without sympathetic inputs to the right SMG (SD rats), AEA inhibited the MC-induced salivary secretion, as observed in intact rats (Figure 2C).

Effect of AEA, AM251 and bicuculline injected icv on MC-stimulated salivary secretion

Intracerebroventricular injections of AM251, a CB1 receptor antagonist $(500 \mathrm{ng} / 5 \mu \mathrm{L}), 15 \mathrm{~min}$ before the injection of AEA, blocked the inhibitory effect of AEA on MCinduced salivary secretion (Table 1). The injection of AM251 alone did not significantly alter MC-induced salivary secretion compared to control curves constructed before the injection of the antagonist. We also showed that the inhibitory effect of AEA on MC-induced salivary secretion was prevented completely by injecting bicuculline $(25 \mathrm{ng} / 5 \mu \mathrm{L}$, icv), a $\mathrm{GABA}_{\mathrm{A}}$ receptor blocker, $15 \mathrm{~min}$ prior to the injection of AEA (Table 1).

Effect of AEA, AM630 and capsazepine injected icv on MC-stimulated salivary secretion

Neither injections of AM630 (500 ng/5 $\mu \mathrm{L}$ vehicle, icv), a CB2 receptor antagonist, nor injections of capsazepine ( $2 \mu \mathrm{g} / 5 \mu \mathrm{L}$ vehicle, icv), a vanilloid receptor antagonist, 15 min before the injection of AEA, prevented the inhibitory effect of AEA on MC-induced salivary secretion (Table 2). Neither AM630 nor capsazepine alone modified MC-induced salivary secretion.

\section{Hypothalamic localization of CB1 receptors}

Immunohistochemical studies showed a high density of cells and fibers immunostained for CB1, distributed in the lateral area of the hypothalamus, a zone involved in the regulation of salivary secretion (Figure 3 ).

\section{Discussion}

Sialogogues can act on hypothalamic receptors to induce salivation (29-31). Moreover, it has been reported that the muscarinic antagonist atropine injected icv reduced salivation induced by the muscarinic agonist pilocarpine injected ip, suggesting that pilocarpine enters the brain and acts on central muscarinic receptors, activating autonomic efferent fibers to induce salivation $(3,31)$. Addi- 
tionally, it was shown that the $\beta$-adrenoreceptor agonist isoproterenol injected icv increased salivary flow, demonstrating the participation of a central adrenergic system in the regulation of salivary secretion (32). Moreover, removal of the SCG as well as systemic injection of $\alpha$ adrenoceptor antagonists reduced the icv pilocarpine-stimulated salivation by $40 \%$ compared to sham-operated rats (33). This evidence suggests that sympathetic nerves involved in salivary secretion could be stimulated by direct
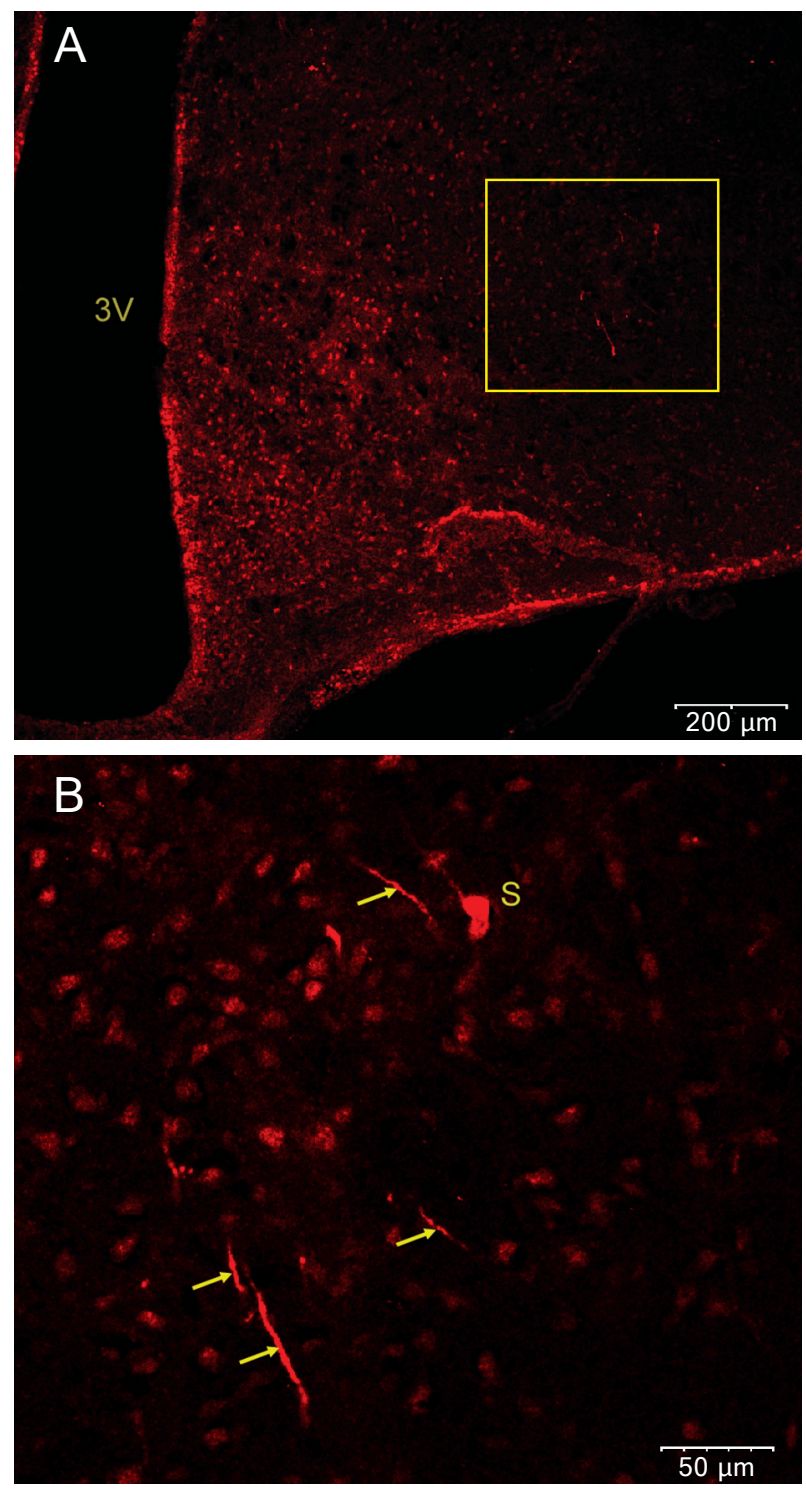

Figure 3. Distribution of $C B 1$ receptors in the lateral area of the hypothalamus (Panel A). 3V, third ventricle. Panel B, Magnification of the area within the square in panel $A$ showing the location of CB1-r immunoreactivity. S, Neuronal soma immunostained for CB1; arrows indicate neuronal fibers immunostained for CB1. Original magnification: A, 40X; B, 160X. activation of brain cholinergic receptors. Therefore, sialogogues injected through the femoral vein act not only on their receptors in the SMG, but also on their receptors in the brain, stimulating efferent responses at the periphery.

The present study demonstrates for the first time that AEA centrally inhibits salivary secretion by acting on CB1 receptors located in the brain and thus, decreasing parasympathetic neurotransmission to the SMG, additionally to the local action on CB1 and CB2 receptors in the SMG, previously reported (18). We first evaluated the effect of parasympathetic decentralization or of sympathetic denervation and of both situations together in order to determine the degree of participation of both autonomic divisions in the induction of salivation. The results showed that parasympathetic decentralization by cutting the chorda tympani greatly decreased the saliva secretion induced by MC. On the other hand, sympathetic denervation decreased saliva secretion only slightly.

There are abundant reports describing the effects of exo- and endocannabinoids on autonomic neurotransmission. It was reported that the activation of $\mathrm{CB} 1$ receptors by THC and AEA causes hypotension via a sympatho-inhibitory action in rats (21). These effects are related to presynaptic inhibition of norepinephrine exocytosis, since AEA and $\mathrm{THC}$ abolish norepinephrine release from isolated rat atria and vasa deferentia, and SR141716A, a selective CB1 antagonist, competitively reversed these effects. Moreover, WIN55212-2 and CP55940, synthetic cannabinoid receptor agonists, inhibited presynaptically the sympathetic cardio-accelerator response in the rabbit by activating heart CB1 receptors (34). Also, bradycardia evoked by stimulating the vagus nerve was inhibited by WIN552122 and CP55940 through CB1 receptors. Our results suggest that $A E A$ injected icv inhibits salivary secretion by decreasing parasympathetic neurotransmission, with no effect on sympathetic neurotransmission, since there was no inhibitory effect in addition to that produced by severing the chorda tympani nerve. Along the same line, when the SCG was removed, the injection of AEA decreased salivation to an extent similar to that observed in rats without surgery.

Additionally, we showed by immunohistochemistry the presence of CB1 receptors in the lateral hypothalamus, which is an important area for the control of salivary secretion $(4,5)$. These results agree with other publications that demonstrated the presence of specific binding for CB1 receptors in the lateral hypothalamic area (35). Furthermore, we demonstrated that the inhibitory effect of $A E A$ on salivary secretion was mediated by activation of $\mathrm{CB} 1$ receptors, since AM251, a CB1 specific antagonist, blocked this inhibitory effect. The Ki of AM251 and AEA for CB1 is 
7.49 and $89 \mathrm{nM}$, respectively (36). Therefore, the dose of AM251 (500 ng/5 $\mu \mathrm{L}, 180 \mu \mathrm{M}$ ) used was 10-fold higher than the dose of AEA (50 ng/5 $\mu \mathrm{L}, 28 \mu \mathrm{M})$, resulting in affinity binding of the antagonist exceeding at least 100 times the agonist, ensuring the blockade of the receptors. Also, abundant CB2 receptor immunoreactivity in neuronal and glial processes was detected in the brain (37). However, we observed that the CB2 receptor antagonist, AM630 (500 ng/5 $\mu \mathrm{L}$ ), injected icv did not affect the inhibitory effect of AEA on MC-induced salivary secretion, showing that CB2 receptors are probably not involved in the central control of salivation. Also, TRPV1 channels can be activated by $A E A$ and were reported to be located in the brain $(23,38)$. Therefore, they could be implicated in this inhibitory modulation. However, we observed that capsazepine, a TRPV1 selective antagonist, injected icv did not prevent the inhibitory effect of AEA on salivary secretion.

Mitoh et al. (39) demonstrated that superior salivatory neurons located in the lateral reticular formation receive excitatory (glutamatergic) and inhibitory (GABAergic) synaptic transmission in rats, and that the activation of $\mathrm{GABA}_{\mathrm{A}}$

\section{References}

1. Lung MA. Autonomic nervous control of myoepithelial cells and secretion in submandibular gland of anaesthetized dogs. J Physiol 2003; 546: 837-850.

2. Tandler B, Phillips CJ. Microstructure of mammalian salivary glands and its relationship to diet. In: Garret JR, Ekstrom J, Anderson LC (Editors), Vol. 10. Glandular mechanisms of salivary secretion. Oral frontiers on biology. Basel: Switzerland: Karger; 1998. p 21-35.

3. Renzi A, Colombari E, Mattos Filho TR, Silveira JE, Saad WA, Camargo LA, et al. Involvement of the central nervous system in the salivary secretion induced by pilocarpine in rats. J Dent Res 1993; 72: 1481-1484.

4. Matsuo R, Kusano K. Lateral hypothalamic modulation of the gustatory-salivary reflex in rats. J Neurosci 1984; 4: 1208-1216.

5. Hainsworth FR, Epstein AN. Severe impairment of heatinduced saliva-spreading in rats recovered from lateral hypothalamic lesions. Science 1966; 153: 1255-1257.

6. Flynn FW, Evey LA, Mitchell JC. Heat-induced saliva secretion and thermoregulation in female rats with ventromedial hypothalamic lesions. Physiol Behav 1981; 26: 779-782.

7. Kanosue K, Nakayama T, Tanaka H, Yanase M, Yasuda H. Modes of action of local hypothalamic and skin thermal stimulation on salivary secretion in rats. J Physiol 1990; 424: 459-471.

8. Devane WA, Dysarz FA III, Johnson MR, Melvin LS, Howlett AC. Determination and characterization of a cannabinoid receptor in rat brain. Mol Pharmacol 1988; 34: 605-613.

9. Herkenham M, Lynn AB, Little MD, Johnson MR, Melvin LS, receptors produces hyperpolarization in mature neurons that probably leads to the reduction of salivary secretion (40). Our results suggest that $\mathrm{CB} 1$ receptors respond to AEA by increasing GABAergic neurotransmission, since bicuculline, a $\mathrm{GABA}_{\mathrm{A}}$ receptor antagonist, injected icv, totally blocked the inhibitory effect of AEA on salivary secretion. Moreover, we demonstrated previously that GABA release was increased in hypothalamic extracts exposed in vitro to AEA (25). Therefore, our results constitute a relevant contribution to support the participation of endocannabinoids and GABA in the control of salivary secretion. In summary, endocannabinoids inhibit salivary secretion by acting at least at two different levels: a) on cannabinoid receptors in the salivary glands (18) and b) on central $\mathrm{CB} 1$ receptors that respond by inhibiting parasympathetic neurotransmission to the salivary glands.

\section{Acknowledgments}

The authors are greatly indebted to Ricardo Horacio Orzuza for technical assistance.

de Costa BR, et al. Cannabinoid receptor localization in brain. Proc Natl Acad Sci U S A 1990; 87: 1932-1936.

10. Pertwee RG. Cannabinoid receptors. London: Academic Press; 1995

11. Munro S, Thomas KL, Abu-Shaar M. Molecular characterization of a peripheral receptor for cannabinoids. Nature 1993; 365: 61-65.

12. Mechoulam R, Fride E, Di Marzo V. Endocannabinoids. Eur J Pharmacol 1998; 359: 1-18.

13. Gatley SJ, Gifford AN, Volkow ND, Lan R, Makriyannis A. 123I-labeled AM251: a radioiodinated ligand which binds in vivo to mouse brain cannabinoid CB1 receptors. Eur J Pharmacol 1996; 307: 331-338.

14. Rinaldi-Carmona M, Barth F, Heaulme M, Shire D, Calandra B, Congy C, et al. SR141716A, a potent and selective antagonist of the brain cannabinoid receptor. FEBS Lett 1994; 350: 240-244.

15. Rinaldi-Carmona M, Barth F, Heaulme M, Alonso R, Shire $\mathrm{D}$, Congy $\mathrm{C}$, et al. Biochemical and pharmacological characterisation of SR141716A, the first potent and selective brain cannabinoid receptor antagonist. Life Sci 1995; 56: 1941-1947.

16. Pertwee R, Griffin G, Fernando S, Li X, Hill A, Makriyannis A. AM630, a competitive cannabinoid receptor antagonist. Life Sci 1995; 56: 1949-1955.

17. Rinaldi-Carmona M, Barth F, Millan J, Derocq JM, Casellas $\mathrm{P}$, Congy $\mathrm{C}$, et al. SR 144528, the first potent and selective antagonist of the CB2 cannabinoid receptor. J Pharmacol Exp Ther 1998; 284: 644-650. 
18. Prestifilippo JP, Fernandez-Solari J, de la Cal C, Iribarne M, Suburo AM, Rettori V, et al. Inhibition of salivary secretion by activation of cannabinoid receptors. Exp Biol Med 2006; 231: 1421-1429.

19. Wilson RI, Nicoll RA. Endocannabinoid signaling in the brain. Science 2002; 296: 678-682.

20. McConnell WR, Dewey WL, Harris LS, Borzelleca JF. A study of the effect of delta 9-tetrahydrocannabinol (delta 9THC) on mammalian salivary flow. J Pharmacol Exp Ther 1978; 206: 567-573.

21. Ishac EJ, Jiang L, Lake KD, Varga K, Abood ME, Kunos G. Inhibition of exocytotic noradrenaline release by presynaptic cannabinoid $C B 1$ receptors on peripheral sympathetic nerves. Br J Pharmacol 1996; 118: 2023-2028.

22. Nyiri G, Szabadits E, Cserep C, Mackie K, Shigemoto R, Freund TF. GABAB and CB1 cannabinoid receptor expression identifies two types of septal cholinergic neurons. Eur $J$ Neurosci 2005; 21: 3034-3042.

23. Cristino L, De Petrocellis L, Pryce G, Baker D, Guglielmotti $\mathrm{V}$, Di Marzo V. Immunohistochemical localization of cannabinoid type 1 and vanilloid transient receptor potential vanilloid type 1 receptors in the mouse brain. Neuroscience 2006; 139: 1405-1415.

24. Fernandez-Solari J, Scorticati C, Mohn C, De Laurentiis A, Billi S, Franchi A, et al. Alcohol inhibits luteinizing hormonereleasing hormone release by activating the endocannabinoid system. Proc Natl Acad Sci U S A 2004; 101: 32643268 .

25. de Miguel R, Romero J, Munoz RM, Garcia-Gil L, Gonzalez $S$, Villanua MA, et al. Effects of cannabinoids on prolactin and gonadotrophin secretion: involvement of changes in hypothalamic gamma-aminobutyric acid (GABA) inputs. Biochem Pharmacol 1998; 56: 1331-1338.

26. Bianciotti LG, Elverdin JC, Vatta MS, Colatrella C, Fernandez BE. Atrial natriuretic factor enhances induced salivary secretion in the rat. Regul Pept 1994; 49: 195-202.

27. Pellegrino LJ, Pellegrino AS, Ashman AJ. A stereotaxic atlas of the rat brain. 2nd edn. New York: Plenumn Press; 1979.

28. Kaniucki MD, Elverdin JC, Luchelli-Fortis MA, Perec CJ, Stefano FJ. Sympathetic and parasympathetic nerves regulate postsynaptic alpha-2 adrenoceptor in salivary glands. $J$ Pharmacol Exp Ther 1986; 239: 488-493.

29. Renzi A, De Luca LA Jr, Menani JV. Lesions of the lateral hypothalamus impair pilocarpine-induced salivation in rats. Brain Res Bull 2002; 58: 455-459.

30. Moreira TS, Takakura AC, De Luca LA Jr, Renzi A, Menani
JV. Inhibition of pilocarpine-induced salivation in rats by central noradrenaline. Arch Oral Biol 2002; 47: 429-434.

31. Takakura AC, Moreira TS, Laitano SC, de Luca Junior LA, Renzi A, Menani JV. Central muscarinic receptors signal pilocarpine-induced salivation. J Dent Res 2003; 82: 993997.

32. Saad WA, Guarda IF, Guarda RS, Camargo LA, dos Santos TA, Saad WA, et al. Role of nitric oxide and beta-adrenoceptors of the central nervous system on the salivary flow induced by pilocarpine injection into the lateral ventricle. Pharmacol Biochem Behav 2002; 72: 229-235.

33. Cecanho R, Anaya M, Renzi A, Menani JV, De Luca LA Jr. Sympathetic mediation of salivation induced by intracerebroventricular pilocarpine in rats. J Auton Nerv Syst 1999; 76: 9-14.

34. Szabo B, Nordheim U, Niederhoffer N. Effects of cannabinoids on sympathetic and parasympathetic neuroeffector transmission in the rabbit heart. J Pharmacol Exp Ther 2001; 297: 819-826.

35. Fernandez-Ruiz JJ, Munoz RM, Romero J, Villanua MA, Makriyannis A, Ramos JA. Time course of the effects of different cannabimimetics on prolactin and gonadotrophin secretion: evidence for the presence of $C B 1$ receptors in hypothalamic structures and their involvement in the effects of cannabimimetics. Biochem Pharmacol 1997; 53: 19191927.

36. Adams IB, Ryan W, Singer M, Thomas BF, Compton DR, Razdan RK, et al. Evaluation of cannabinoid receptor binding and in vivo activities for anandamide analogs. J Pharmacol Exp Ther 1995; 273: 1172-1181.

37. Onaivi ES. Neuropsychobiological evidence for the functional presence and expression of cannabinoid CB2 receptors in the brain. Neuropsychobiology 2006; 54: 231-246.

38. Zygmunt PM, Andersson DA, Hogestatt ED. Delta 9-tetrahydrocannabinol and cannabinol activate capsaicin-sensitive sensory nerves via a CB1 and CB2 cannabinoid receptor-independent mechanism. J Neurosci 2002; 22: 47204727.

39. Mitoh Y, Funahashi M, Kobashi M, Matsuo R. Excitatory and inhibitory postsynaptic currents of the superior salivatory nucleus innervating the salivary glands and tongue in the rat. Brain Res 2004; 999: 62-72.

40. Mitoh Y, Funahashi M, Fujii A, Fujita M, Kobashi M, Matsuo $R$. Development of inhibitory synaptic transmission to the superior salivatory nucleus in rats. Brain Res 2008; 1191: 47-54. 